\title{
PENGARUH FAKTOR TENAGA KERJA YANG DIMODERASI OLEH STRATEGI PENINGKATAN PENGAWASAN IMPLEMENTASI KESELAMATAN KERJA TERHADAP KECELAKAAN KERJA DI PT SEMEN PADANG
}

\author{
Dainuri ${ }^{1}$, Sari Arlinda ${ }^{2}$, Hendra Lukito ${ }^{3}$ \\ (Universitas Andalas ${ }^{1,3}$, Poltekkes Kemenkes Padang ${ }^{2}$ )
}

\begin{abstract}
Occupational Health and Safety $(K 3)$ is one of the requirements to increase company productivity in order to be able to compete and survive in the era of globalization in the world free market economy. PT Semen Padang, as the largest industry in West Sumatra, is engaged in producing and trading cement, experiencing work accident problems. This study aims to determine the influence of internal and external labor factors moderated by the strategy of increasing the supervision of the implementation of work safety on work accidents at PT Semen Padang. The research method was a cross-sectional survey by interviewing 165 respondents who were selected by simple random sampling from a population of 423 people based on the formula of Issac and Michael. The results showed that the Variable Strategy for the Improvement of the Implementation of Work Safety Supervision (K3) was $0.019<0.05$, which means that the Strategy for Improving the Implementation of Safety Supervision had an influence on internal factors on work accidents. There is no significant effect on external factors with a value of $0.277>0.05$ on work accidents. The conclusion is that the better the internal and external factors in the workforce, the smaller the work accident rate. It is recommended that a supervisory program related to work stress and fatigue, supporting facilities and infrastructure and appropriate work tools be added to the OHS Supervision Improvement Strategy program.
\end{abstract}

Keywords: Work safety supervision strategy; Implementation of work safety; Work Accident

\begin{abstract}
Abstrak
Keselamatan dan Kesehatan Kerja (K3) adalah salah satu syarat meningkatkan produktivitas perusahaan agar mampu bersaing, bertahan hidup di era globalisasi ekonomi pasar bebas dunia. PT Semen Padang sebagai industri terbesar di Sumatera Barat bergerak memproduksi dan memperdagangkan semen mengalami permasalahan kecelakaan kerja. Penelitian ini bertujuan mengetahui pengaruh faktor internal dan eksternal tenaga kerja yang dimoderasi oleh strategi peningkatan pengawasan implementasi keselamatan kerja terhadap kecelakaan kerja di PT Semen Padang. Metode penelitian adalah survey crosssectional dengan mewawancarai 165 responden yang dipilih secara simple random sampling dari populasi 423 orang berdasarkan rumus Issac dan Michael. Hasil penelitian menunjukkan Variabel Strategi Peningkatan Implementasi pengawasan Keselamatan Kerja (K3) ialah 0,019<0,05, artinya Strategi Peningkatan Implementasi pengawasan Keselamatan Kerja memiliki pengaruh pada faktor Internal terhadap kecelakaan kerja. Pada Faktor Eksternal tidak ada pengaruh signifikan dengan nilai 0,277 > 0,05 terhadap kecelakaan kerja. Kesimpulan semakin baik faktor internal dan ekternal tenaga kerja maka semakin kecil tingkat kecelakaan kerja. Disarankan program pengawasan terkait stress dan kelelahan kerja, sarana dan prasarana pendukung dan alat kerja yang layak ditambahkan dalam program Strategi Peningkatan Pengawasan K3.
\end{abstract}

Kata kunci : Strategi pengawasan K3; Implementasi keselamatan kerja; Kecelakaan Kerja. 


\section{PENDAHULUAN}

Pasar bebas dunia atau era globalisasi ekonomi, di asean disebut Asean Free Trade Ageement (AFTA), Internasional dikenal dengan World Trade Organization (WTO) dan di Asia Pasific dikenal dengan Asia Pacific Ecomoic Community (APEC) yang mulai berlaku tahun 2020, merupakan tantangan bagi produsen di segala kegiatan ekonomi.Keselamatan dan kesehatan kerja (K3) merupakan salah satu persyaratan untuk meningkatkan produktivitas kerja karyawan untuk mampu bersaing dan bertahan hidup ${ }^{1}$. Namun masih sangat di sayangkan dan bahkan memprihatinkan jumlah kecelakaan kerja terhadap pekerja atau tenaga kerja masih terlalu tinggi dan menjadi masalah dunia.Data Word Safety mengungkap bahwa setiap tahunnya terjadi 270 juta kecelakaan kerja, tenaga kerja yang meninggal karena kecelakaan 355.000 orang pertahunnya, sepertiganya kehilangan hari kerja adalah 4 atau lebih hari kerja. Kematian oleh kecelakaan dan penyakit akibat kerja per harinya adalah 5.000 orang, 4\% Gross Domestic Product (GDP) dunia atau US\$1.251.353 juta hilang oleh membiayai cidera, kematian dan penyakit ${ }^{2}$

Di Indonesia upaya perlindungan terhadap tenaga kerja secara sistim sudah diaturdengan perundangan tentang KeselamatanKerja, UU No. 1 tahun 1970 yang diperkuat oleh Permenaker No 5 tahun 1996,tentang Sistim Manajemen Keselamatan dan Kesehatan Kerja (SMK3), yang kemudian diperbaharui dengan Peraturan Pemerintah (PP) Nomor 50 tahun 2012. SMK3 bertujuan untuk mensinergikan sistim keselamatan kerja tersebut dengan sistim-sistim manajemen yang ada diperusahaan, sehingga efektifitas perlindungan K3 bagi pekerja terjamin dan meningkat, ${ }^{3}$. Berdasarkan data Badan Penyelenggara Jaminan Kesehatan Tenaga Kerja (BPJS Ketenagakerjaan) daritahun 2015 sampai tahun 2018 menunjukkan kasus kecelakaan kerja masih berada pada puluhan ribu dan ratusan ribu per tahun. tahun 2015 angka kecelakaan kerja di Indonesia sebesar 105.182 kasus, dimana 2\% nya adalah kasus kecelakaan berat berakibat kematian, tahun 2016 terdapat penurunan dibanding tahun 2015, namun masih sedikit karena kasus kecelakaan kerja masih melebihi angka seratus ribu, yaitu 101.367 kasus, pada tahun 2017 angka kecelakaan kerja meningkat kembali sebesar 123.041 dan pada tahun 2018; 147.000 kasu s ${ }^{4-5}$.

Secara skala provinsi, kasus terjadinya kecelakaan akibat kerja, pada Industri sebagai contoh di Sumatera Barat dari tahun 2014 sampai dengan tahun 2017 trendnya juga meningkat, ${ }^{6}$ tahun 2014 sebanyak 408 kasus, tahun 2015 sebanyak 689 kasus, tahun 2016 terdapat 1.295 kasus dan tahun 2017 terjadi 905 kasus kecelakaan akibat kerja dan pada tahun 2018 terdapat kasus kecelakaan kerja sebanyak 12857. Penyebab terjadinya kecelakaan kerja di tempat kerja, disebabkan oleh 2 (dua) faktor yaitu kondisi yang tidak aman (faktor selain manusia); pengolahan bahan, mesin penggerak, dan pengangkat ${ }^{8}$ dan akibat tindakan karyawan yang tidak aman atau kesalahan manusia ${ }^{2}$, bisa dari alasan fisiologis (kelelahan, kurang tidur, alasan fisik dan penyakit), kesadaran keamanan dan 
kecakapan kerja, keadaan mental dan kebiasaan operasi, emosional dan hubungan dengan mitra sesama pekerja. ${ }^{9}$

PT Semen Padang merupakan salah satu industri terbesar di Sumatera Barat yang bergerak dalam memproduksi dan perdagangan semen, tidak luput dari permasalahan kecelakaan kerja, tahun 2014 tercatat 12 kasus, tahun 2015 dilaporkan 14 kasus, tahun 2016 terjadi 15 kejadian kecelakaan kerja, namun pada tahun 2017 terdapat penurunan angka kasus kecelakaan kerja yaitu 11 kasus sedangkan tahun 2018 jumlah kecelakaan kerja sebanyak 6 kasus $^{8}$.Keberhasilan PT Semen Padang dalam menurunkan angka kecelakaan kerja tersebut tidak terlepas dari dilakukannya upaya-upaya dan strategi, yaitu Strategi peningkatan implementasi pengawasan yang diterapkan sejak tahun 2017 dalam bentuk 5P + 1E (Pengawasan, Pemantauan, Pengukuran, Perizinan, Pelaporan dan Penanggulangan Keadaan darurat).Tujuan Penelitian adalah untuk mengetahui hubungan antara Strategi Peningkatan Implementasi Pengawasan K3 yang dilakukan oleh PT Semen Padang terhadap penurunan angka kecelakaan kerja. Fokus dalam penelitian ini adalah Pengawasan atau Inspeksi yang dilaksanakan, sedangkan inisiatif strategi lainnya tidak akan dijelaskan secara detail.

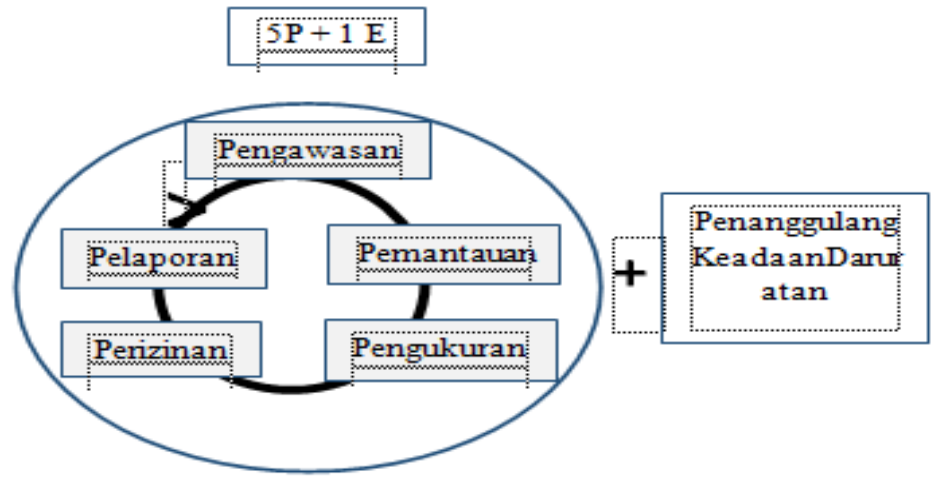

\section{Gambar 1 : Strategi 5P + 1E Biro HSE PT.Semen Padang}

\section{METODE PENELITIAN}

Penelitian ini merupakan penelitian kuantitatif menggunakan teknik pengumpulan data dengan survey melalui kuesioner yang terstruktur yang telah diuji validitas dan reabilitasnya, dengan pendekatan secara cross-sectional. Populasi penelitian ini adalah seluruh karyawan organik PT Semen Padang yang bekerja di pabrik tahun 2019 berjumlah 423 orang, dan berdasarkan tabel rumus sampel Issac dan Michael ditetapkan perhitungan $10 \%$ dari jumlah populasi sebagai sample yaitu 165 responden, kemudian dilakukan wawancara dan dipilih berdasarkan simple random sampling. Variabel dependen pada penelitian ini adalah kecelakaan kerja, yaitu kecelakaan yang terjadi pada diri pekerja saat melaksanakan pekerjaan, yang menimbulkan kerugian sebagai akibat dari inspeksi K3 tidak dilaksanakan dan temuan inspeksi tidak ditindaklanjuti, serta tidak adanya peningkatan tindakan 
perbaikan keselamatan. Variable Independent adalah faktor internal tenaga kerja yaitu kondisi yang timbul dari dalam diri tenaga kerja yang mendorongnya untuk bertindak atau berperilaku terhadap pekerjaan.

Perilaku aman selalu berhati-hati dalam bekerja, memahami prosedur kerja yang aman, menghindari tindakan yang tidak aman, menjaga kebersihan dan kerapian area tempat kerja, aktif melaporkan kecelakaan, luka, sakit, dan tindakan dan kondisi yang berisiko, bekerjasama dalam inspeksi dan analisis risiko pekerjaan, taat aturan keamanan, berinisiatif bekerja dengan lebih baik, aktif dalam pelatihan keselamatan dan faktor eksternal tenaga kerja, yaitu faktor penyebab dari luar diri tenaga kerja yang mendorong partisipasi pekerja; Komitmen dan kebijakan K3 manajemen puncak, Pelatihan keselamatan, Poster dan propaganda. Variable Moderasi adalah Strategi peningkatan pengawasan implementasi keselamatan kerja (K3) yaitu Strategi perusahaan untuk mencapai misi terkait keselamatan dan kesehatan kerja, berupa penyediaan program, prosedur dan anggaran yang bertujuan untuk meminimalisir terjadinya kecelakan kerja. Data penelitian dinalisis secara deskriptif dan pengujian hipotesis dilakukan dengan regresi linear berganda.

\section{HASIL PENELITIAN}

Analisis Univariat merupakan analisis yang digunakan untuk melihat distribusi frekuensi pada masing-masing variable penelitian ${ }^{12}$. Gambaran umum responden penelitian tersebut satu per satu dapat diuraikan sebagai berikut:

Tabel 1. Karakteristik Responden

\begin{tabular}{|c|c|c|c|c|}
\hline & Karakteristik & Deskripsi & Frekuensi & Persentase (\%) \\
\hline \multirow[t]{2}{*}{1} & JenisKelamin & a. Laki-laki & 112 & 93,33 \\
\hline & & b. Perempuan & 8 & 6,67 \\
\hline \multirow{3}{*}{2} & Statuc Pormikenon & a. Menikah & 113 & 94,17 \\
\hline & status remmikaltan & b. Belum Menikah & 5 & 4,17 \\
\hline & & c. JandaatauDuda & 2 & 1,67 \\
\hline \multirow{3}{*}{3} & Usia & a. $21-30$ tahun & 23 & 19,17 \\
\hline & Usta & b. $31-40$ tahun & 43 & 35,83 \\
\hline & & c. $41-50$ tahun & 54 & 45,00 \\
\hline \multirow[t]{2}{*}{4} & Jabatan & a. StafKepalaUrusan (Eselon 4) & 40 & 33,33 \\
\hline & & b. Non-Staf (Eselon 5) & 80 & 66,67 \\
\hline \multirow{4}{*}{5} & Maca Koria & a. $\leq 5$ tahun & 15 & 12,50 \\
\hline & Ivasa nerja & b. $6-10$ tahun & 30 & 25,0 \\
\hline & & c. $11-15$ tahun & 34 & 28,33 \\
\hline & & c. $>15$ tahun & 41 & 34,17 \\
\hline \multirow{4}{*}{6} & & a. $\leq 5$ perbulan & 12 & 10,00 \\
\hline & rendapatan & b. $6-10$ juta per bulan & 58 & 48,33 \\
\hline & & c. $11-15$ juta per bulan & 44 & 37,67 \\
\hline & & d. $>15$ juta per bulan & 6 & 5,00 \\
\hline \multirow{4}{*}{7} & & a. SLTA Sederajat & 46 & 38,33 \\
\hline & Penaldikan & b. Diploma ( D1-D4) & 28 & 23,33 \\
\hline & & c. Sarjana & 43 & 35,83 \\
\hline & & d. Magister & 3 & 2,50 \\
\hline \multicolumn{3}{|c|}{ Total Responden } & 120 & \\
\hline
\end{tabular}


Berdasarkan tabel 1, dapat dilihat bahwa responden umumnya berjenis kelamin laki-laki yaitu sebanyak 93,33\%, dengan status pernikahan sebanyak94,17\%. Sebagian besar responden berumur diatas 30 tahun yaitu sebesar $80,83 \%$ dengan jabatan non-staf (pelaksana) yaitu sebanyak $66,67 \%$, dan $34,17 \%$ telah bekerja selama $>15$ tahun. Jumlah pendapatan paling banyak 6-10 juta per bulan yaitu sebesar 48,33\%, dan 38,33\% berpendidikan SLTA sederajat. Untuk mengetahui seberapa besar pengaruh variabel Internal, Eksternal, dengan Strategi Peningkatan Pengawasan Implementasi Keselamatan sebagai variable moderasi dilakukan analisis regresi linear berganda sebagai berikut :

Tabel 2. Hasil Analisis Regresi Linear Berganda variable Internal, Eksternal, dan Strategi Peningkatan Pengawasan Implementasi Keselamatan Kerja di PT Semen Padang.

\begin{tabular}{|c|c|c|c|c|c|c|c|}
\hline VARIABEL & B & SE & $\mathrm{t}$ & $\mathrm{R}$ & $\begin{array}{c}R \\
\text { Square }\end{array}$ & $\begin{array}{l}\text { Adjusted } \\
\text { R } \\
\text { Square }\end{array}$ & Sig. \\
\hline Konstanta & 26,851 & 8,929 & 3,007 & \multirow[t]{4}{*}{$0,400 a$} & \multirow[t]{4}{*}{0,16} & \multirow[t]{4}{*}{0,138} & 0,003 \\
\hline Faktor Internal & 0,353 & 0,161 & $-2,187$ & & & & 0,031 \\
\hline Faktor Eksternal & 0,815 & 0,231 & 3,528 & & & & 0,001 \\
\hline $\begin{array}{l}\text { Faktor Strategi Peningkatan } \\
\text { Pengawasan Implementasi } \\
\text { Keselamatan Kerja }\end{array}$ & 0,616 & 0,306 & $-2,015$ & & & & 0,046 \\
\hline
\end{tabular}

a. Prediktor: (konstanta), Pengawasan, Faktor Internal, Faktor Eksternal

b. Variable Bebas: Kecelakaan Kerja

Berdasarkan table 2 diatas dapat dilihat bahwa semua variable (faktor internal, eksternal, dan Strategi Peningkatan Pengawasan Implementasi Keselamatan Kerja) mempunyai hubungan yang bermakna terhadap kejadian kecelakaan kerja pada PT Semen Padang. Nilai koefisien korelasi linear adalah 0,400 dan nilai koefisien determinasi linear berganda (Adjusted $R$ Square) menunjukan angka 0,138. Didapatkan persamaan regresi sebagai berikut:

$$
Y=26,851-0,353 X 1+0,815 X 2-0,616 \times 3
$$

Dari persamaan regresi berganda tersebut terlihat bahwa faktor Internal meningkat sebesar satu satuan maka kecelakaan kerja akan menurun sebesar 0,353, dengan asumsi variable Faktor Eksternal Tenaga Kerja, dan Variabel Strategi Peningkatkan Pengawasan Implementasi K3 adalah tetap. Peningkatan satu satuan Faktor Eksternal akan meningkatkan kecelakaan kerja sebesar 0,815 dengan asumsi variable Faktor Internal dan Strategi Peningkatkan Pengawasan Implementasi Keselamatan kerja adalah tetap.Strategi Peningkatkan Pengawasan Implementasi Keselamatan kerja meningkat satu satuan,maka kecelakaan kerja akan menurun sebesar 0,616 dengan asumsi variable Faktor Internal Tenaga Kerja dan Faktor Eksternal Tenaga Kerja adalah tetap. 
Hubungan antara variable bebas terhadap variable terikat ditunjukan dengan adanya variable Moderasi penelitian yaitu Strategi peningkatan pengawasan implementasi keselamatan kerja

Tabel 3. Hasil Analisis variable moderasi Strategi Peningkatan Pengawasan Implementasi Keselamatan Kerja terhadap variable Internal dan Eksternal di PT Semen Padang.

\begin{tabular}{lcccc}
\hline \multicolumn{1}{c}{ VARIABEL } & $\mathrm{B}$ & $\mathrm{SE}$ & $\mathrm{t}$ & Sig. \\
\hline Konstanta & $-51,454$ & 54,082 & $-0,951$ & 0,343 \\
\hline Faktor Internal & 1,955 & 0,984 & 1,986 & 0,049 \\
\hline FaktorEksternal & $-0,042$ & 0,763 & $-0,055$ & 0,956 \\
\hline $\begin{array}{l}\text { Faktor Strategi Peningkatan Pengawasan } \\
\text { Implementasi Keselamatan Kerja }\end{array}$ & 2,035 & 2,024 & 1,005 & 0,317 \\
\hline Z1 (Fak. Internal x Var.Pengawasan) & $-0,081$ & 0,034 & $-2,720$ & 0,019 \\
\hline Z2 (Fak.Eksternal xVar. Pengawasan) & 0,032 & 0,029 & 1,091 & 0,277 \\
\hline
\end{tabular}

Dari tabel 3 terlihat nilai signifikansi pengaruh faktor internal terhadap kecelakaan kerja dengan dimoderasi oleh Variabel Strategi Peningkatan Implementasi pengawasan Keselamatan Kerja (K3) ialah 0,019 <0,05, hal ini berarti Strategi Peningkatan Implementasi pengawasan Keselamatan Kerja memiliki pengaruh dan signifikan pada variabel faktor Internal terhadap kecelakaan kerja. Sementara pada variabel Faktor Eksternal tidak memberikan pengaruh signifikan dengan nilai 0,277 >0,05 terhadap kecelakaan kerja.

\section{PEMBAHASAN}

Hasil analisis faktor internal terhadap kecelakaan kerja mempengaruhi tingkat kecelakaan kerja yang terjadi dengan nilai koefisien korelasi linear adalah 0,400, artinya menunjukkan hubungan yang lemah terhadap variable independen.Hasil ini memberikan pengertian bahwa setiap peningkatan faktor internal akan berdampak pada kecelakaan kerja pada karyawan PT Semen Padang, artinya semakin baikf aktor internal pada diri karyawan,maka akan berpengaruh menurunkan tingkat kecelakaan kerja. Penelitian ini sejalan dengan penelitian sebelumnya yang diteliti oleh Yahya Khosravi(2015) yang melakukan studi terkait faktor yang mempengaruhi perilaku yang tidak selamat dan kecelakaan pada usaha konstruksi, dari 8 (delapan) kategori yang dianalisis pada penelitian tersebut, bahwa karakter individu (individual characteristics) merupakan faktor yang berkontribusi positif terhadap performan keselamatan (safety performance) ${ }^{13}$

Fakta dari penelitian ini menunjukkan bahwa faktor internal berpengaruh signifikan terhadap kecelakaan kerja. Lebih jauh menurut Khosravi (2015) faktor terpenting yang mempengaruhi perilaku tidak aman dan kecelakaan adalah karakteristik individu, berupa sikap dan motivasi, usia dan pengalaman ${ }^{13}$. Dari karakteristik responden dapat dilihat bahwa responden dalam penelitian ini paling dominan berumur 41-50 tahun dengan jumlah $45 \%$ 
atausekitar 54 responden dan berumur 31-40 tahun dengan jumlah 35,83\% atau sekitar 43 responden. Artinya sebagian besar karyawan sudah mapan dalam berfikir atau sudah dewasa, sehingga mereka lebih terkontrol dalam bertindak pada pekerjaan mereka demikian juga dari tingkat pendidikan seseorang berpengaruh terhadap perilaku dalam bertindak.

Faktor Ekternal merupakan faktor berkaitan dengan alat, system, lingkungan tempat bekerja. Berdasarkan hasil analisis didapatkan hubungan yang bermakna antara faktor eksternal terhadap kecelakaan kerja. Hasil ini memberikan pengertian bahwa setiap peningkatan Faktor Ekternal akan berdampak pada kecelakaan kerja di PT Semen Padang, artinya semakin baik Faktor Ekternal yang diberikan PT Semen Padang maka akan berpengaruh terhadap kecelakaan kerja. Penelitian ini sejalan dengan penelitian sebelumnya yang diteliti oleh Joanna Tabor (2016) terkait, analisis dan penilaian budaya keselamatan di perusahaan manufaktur, menggunakan pendekatan berbasis pada studi tentang penyebab kecelakaan di tempat kerja, hasil studi tersebut ditemukan bahwa budaya keselamatan merupakan bagian yang penting dari kesehatan dan keselamatan di tempat kerja dan berpengaruh terhadap kecelakaan kerja.

Dari sepuluh item pernyataan yang diajukan,kebanyakan responden menyetujui semua pernyataan, dengan rata-rata tertinggi tanggapan 4,58yaitu untuk pernyataan terkait pentingnya pelatihan $\mathrm{K} 3$ dan rata-rata terendah 4,03 dengan pernyataan terkait penyediaan alat penerangan (lampu) di lokasi kerja.Dari karakteristik responden dapat dilihat bahwa rata-rata responden masih terdapat responden dengan kisaran umur yaitu 21 - 30 tahun dan masa kerja $\leq 5$ tahun, hal ini menunjukan bahwa dalam usia sedemikian kencendrungan mereka akan terpengaruh oleh faktor eksternal saat bekerja terkait keselamatan,sehingga program-program terkait keselamatan sangatlah penting dibuat oleh manajemen. Strategi peningkatan pengawasan implementasi keselamatan kerja merupakan salah satu strategi yang digunakan untuk dapat mengurangi tingkat kecelakaan kerja ${ }^{14}$. Berdasarkan hasil analisis didapatkan bahwa strategi peningkatan pengawasan implementasi keselamatan kerja berpengaruh terhadap tingkat kecelakaan kerja ${ }^{15}$. Hasil ini memberikan pengertian bahwa setiap peningkatan pengawasan implementasi keselamatan kerja akan berdampak pada kecelakaan kerja pada PT Semen Padang, artinyasemakinbagusStrategi peningkatan pengawasan implementasi keselamatan kerja, yang diberikan maka akan berpengaruh terhadap kecelakaan kerja.

Penelitian ini sejalan dengan penelitian sebelumnya yang diteliti oleh Michael $\mathrm{K}$. Lindell (1997) Occupational Safety And Health Inspection Scores Predict Rates Of Workers' Lost-Timelnjuries, Penelitian ini ingin mengidentifikasi efek kausal dari inspeksi terhadap keselamatan pekerja sipil di fasilitas pantai angkatan laut Amerika Serikat (1997), dimana pada penelitian tersebut juga ditemukan bahwa peningkatan $1 \%$ dalam inspeksi 
keselamatan menghasilkan penurunan $1 \%$ yang diharapkan dalam tingkat cedera yang parah pada karyawan ${ }^{15}$.

Fakta dari penelitian ini menunjukkan bahwa Strategi peningkatan pengawasan implementasi keselamatan kerja berpengaruh signifikan terhadap kecelakaan kerja pada karyawan PT Semen Padang. Dari beberapa hal yang dipertimbangkan dalam menentukan Strategi peningkatan pengawasan implementasi keselamatan kerja, dari sepuluh item pernyataan yang diajukan maka tujuh pernyataan memiliki rata-rata 4,12 dengan rata-rata tertinggi 4,64 yaitu untuk pernyataan pengawasan terhadap K3 merupakan hal yang sangat penting dan rata-rata terendah 2,98 dengan pernyataan pengawasan harus dilakukan fleksible (tidak terlalu ketat) oleh atasan. Hal ini berarti bahwa kebanyakan responden menyetujui semua pernyataan tersebut.

\section{SIMPULAN DAN SARAN}

Kesimpulan semakin baik faktor internal dan faktor ekternal tenaga kerja maka semakin kecil atau akan menurunkan tingkat kecelakaan kerja di PT. Semen Padang. Disarankan program pengawasan terkait stress dan kelelahan kerja, penerangan di seluruh area kerja dan penyediaan alat kerja yang layak dan siap dipakai, hendaknya ditambahkan dalam program Strategi Peningkatan Pengawasan K3.

\section{DAFTAR PUSTAKA}

1. Korneilis, Gunawan W. MANFAAT PENERAPANSISTEM MANAJEMEN K3 DALAM UPAYA PENCAPAIAN ZERO ACCIDENT DI SUATU PERUSAHAAN. J Safety Res. 2018;

2. Suma'mur. Buku Higiene Perusahaan dan Kesehatan Kerja (Hiperkes) Edisi 2. Jakarta; 2013.

3. Pemerintah Republik Indonesia. Peraturan Pemerintah Republik Indonesia, No. 50 tahun 2012, tentang Penerapan Sistim Manajemen Keselamatan Kerja. 2012;

4. BPJS. Jumlah kecelakaan kerja di Indonesia masih tinggi.html. [Internet]. Available from: http://www.bpjsketenagakerjaan.go.id/berita/5769/Jumlah kecelakaan kerja di Indonesia masih tinggi.html. Accessed Oktober 20, 2020.

5. Bpjsketenagakerjaan. tahun-2015,-terjadi-105.182-kecelakaan-kerja. Available from: https://www.bpjsketenagakerjaan.go.id/berita/5841/tahun-2015,-terj adi-105.182kecelakaan-kerja.html

6. saeno. sepanjang-2018-kemnaker-catat-terjadi-157.313-kecelakaan-kerja. Available from: https://ekonomi.bisnis.com/read/20190115/12/878723/sepanjang-2018-kemnakercatat-terjadi-157.313-kecelakaan-kerja

7. Sumbar.antaranews.com. jumlah-kecelakaan-kerja. 2018; Available from: 
https://sumbar.antaranews.com/foto/21089

8. Dessler G. Buku Manajemen Sumber Daya Manusia Edisi 14. ed. Bahasa. Jakarta: Salemba Empat.; 2020.

9. Gunawan.FA. Manajemen Keselamatan Operasi. Jakarta: PT.Gramedia Pustaka Utama; 2016.

10. BPJS. BPJS-Ketenagakerjaan-Catat-3.576-Kasus-Kecelakaan-Kerja-di-Riau-danSumbar [Internet]. Available from:

https://www.bpjsketenagakerjaan.go.id/berita/8441/BPJS-Ketenagakerjaan-Catat-3.576Kasus-Kecelakaan-Kerja-di-Riau-dan-Sumbar. Accessed Oktober 22, 2020.

11. Ayers $\mathrm{PA}$, Kleiner $\mathrm{BH}$. New developments concerning managing human factors for safety. Emeraid Insight. 2016;23(7-8):18-23.

12. Joanna TABOR. SAFETY CULTURE IN THE MANUFACTURING ENTERPRISES SELECTED ASPECTS OF EXAMINATION. J Safety Res. 2016;

13. Lindell MK. Occupational safety and health inspection scores predict rates of workers' lost-time injuries. Accid Anal Prev. 2015;29(5):563-71.

14. Khosravi $Y$, Asilian-Mahabadi $H$, Hajizadeh E, Hassanzadeh-Rangi N, Bastani $H$, Behzadan $\mathrm{AH}$. Factors influencing unsafe behaviors and accidents on construction sites: A review. Int J Occup Saf Ergon. 2014;20(1):111-25.

15. Wheelen, Thomas L. and Hunger, David J. Strategic Manajemen and Business Policy,Twelfth Edition. Prantice Hall, New Jersey.; 2010. 